\title{
New Host Records and Description of the Egg of Anacanthorus penilabiatus (Monogenea, Dactylogyridae)
}

\author{
MC Pamplona-Basilio/ ${ }^{+}$, A Kohn, VA Feitosa*
}

Laboratório de Helmintos Parasitos de Peixes, Departamento de Helmintologia, Instituto Oswaldo Cruz-Fiocruz, Av. Brasil 4365, 21045-900 Rio de Janeiro, RJ, Brasil *Departamento de Obras Contra as Secas,

Fortaleza, CE, Brasil

Anacanthorus penilabiatus is referred parasitizing the type-host Piaractus mesopotamicus (Serrasalmidae) and two new hosts, Colossoma macropomum and C. brachypomum (Characidae) from fish ponds of "Departamento Nacional de Obras Contra as Secas", Pentecoste, State of Ceará, Brazil. Table of measurements and the first description of the egg are presented.

Key words: Monogenea - Dactylogyridae - Anacanthorus penilabiatus - fish parasite

The majority of monogenean species in Brazil was described from the Amazonian region. The genus Anacanthorus is represented by 63 species, all of them from the Amazonas River Basin, with the exception of Anacanthorus penilabiatus Boeger, Husak \& Martins, 1995, which was described from the gills of Piaractus mesopotamicus (Holmberg 1887) cultivated in State of São Paulo, Brazil (Kohn \& Cohen 1998). According to Boeger et al. (1995), in artificial environments this species is found in high quantity, suggesting that it may represent a potential risk to fish productivity.

A. penilabiatus was found in the gills of the type-host and in two new hosts, during a survey on fish parasites from Rudolph von Ihering Ichthyological Research Center, "Departamento Nacional de Obras Contra as Secas, DNOCS", Pentecoste, State of Ceará, conducted in April 1996 and August 1998.

The parasites were collected from 5 Piaractus mesopotamicus (Holmberg, 1887) (common named "pacu"), 11 out of 13 Colossoma macropomum (Cuvier, 1818) ("tambaqui") and 4 out of 7 Colossoma brachypomum Cuvier, 1818 ("pirapitinga") examined. They were fixed and stored in formaldehyde 4\%; some specimens were mounted unstained in Hoyer's medium for study of sclerotized structures and others were stained with Gomori's trichrome and mounted in Canada balsam.

${ }^{+}$Corresponding author. Fax: $+55-21-260.4866$. E-mail: mclara@ioc.fiocruz.br

Received 12 May 2000

Accepted 8 February 2001
The morphology of our specimens agrees with the original description, with body slightly wider. The main measurements are presented in a comparative table (Table). Three specimens of $C$. brachyротит presented one egg in uterus not yet described; they are round to oval, 65 to $100 \mu$ long by 48 to $75 \mu$ wide, with a short spine-shape filament, 10 to $14 \mu$ long (Figure).

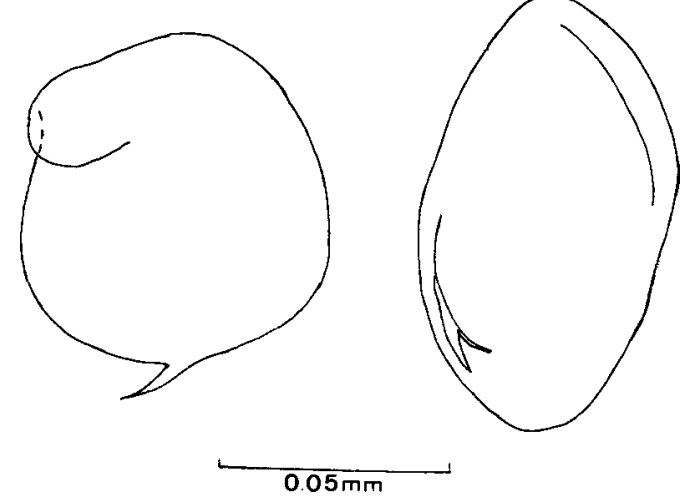

Anacanthorus penilabiatus Boeger et al. (1995). Eggs with a short spine-shape filament

Another species of Dactylogyridae, Linguadactyloides brinkmanni Thatcher \& Kritsky, 1983 and Anacanthorus spathulatus Kritsky, Boeger \& Van Every, 1992 were described from C. macropomum and the later also from C. bidens, all of them from non-cultivated fishes from the Amazon River Basin (Kohn \& Paiva 2000). A. spathulatus is easily differentiated from $A$. penilabiatus by the morphology of the copulatory organ (Boeger et al. 1995). 


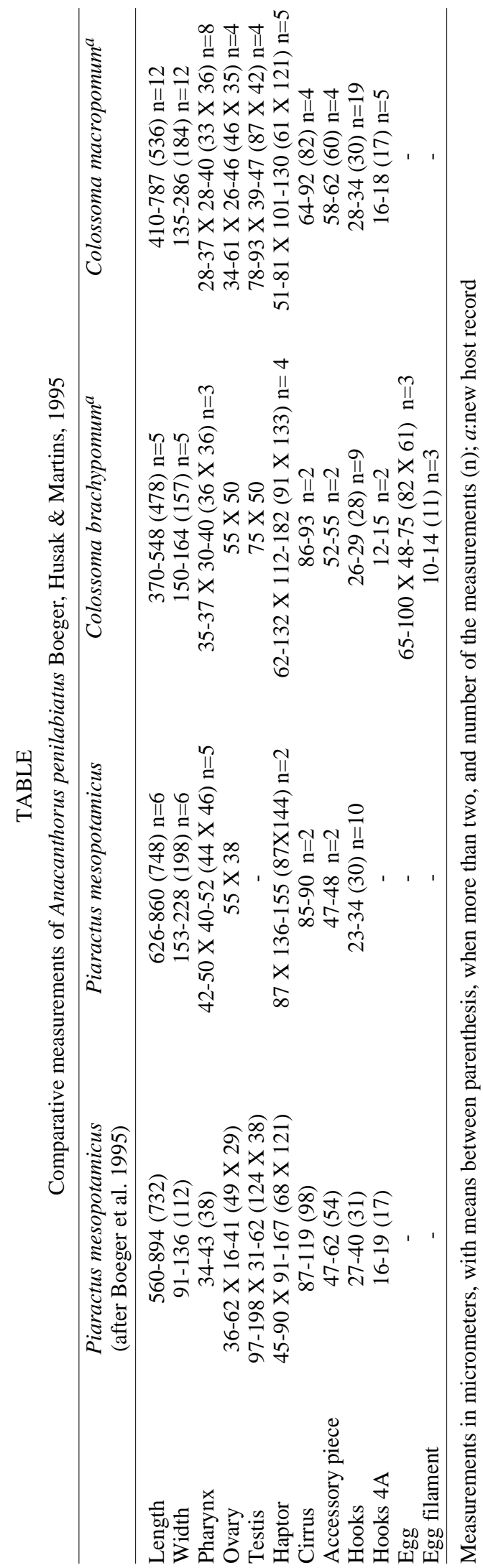

The presence of Monogenea and other parasites in fishes from fish farms and reservoirs of the DNOCS was reported by Békési (1992) without taxonomic classification. This paper contributes to extend the knowledge of the monogenean species in Brazilian regions, which had not been yet explored.

\section{ACKNOWLEDGEMENTS}

To Dr Walter Boeger, Universidade Federal do Paraná, for reviewing the manuscript.

\section{REFERENCES}

Békési L 1992. Evaluation of data on ichthyopathological analyses in the Brazilian northeast. J Braz Assoc Adv Sc 44: 400-403.

Boeger WA, Husak WS, Martins ML 1995. Neotropical monogenoidea. 25. Anacanthorus penilabiatus n. sp. (Dactylogiridae, Anacanthorinae) from Piaractus mesopotamicus (Osteichthyes, Serrasalmidae), cultivated in the State of São Paulo, Brazil. Mem Inst Oswaldo Cruz 90: 699-701.

Kohn A, Cohen SC 1998. South American Monogenea - List of species, hosts and geographical distribution. Inter J Parasitol 28: 1517-1554.

Kohn A, Paiva MP 2000. Fishes parasitised by Monogenea in South America. In G SalgadoMaldonado, AN García-Aldrete, VM Vidal-Martínez (eds), Metazoan Parasites in the Neotropics: A Systematic and Ecological Respective, Inst Biol, Univ Nac Aut México, p. 9-14. 